\title{
The evolution of the ecosystems of thermokarst lakes of the Bolshezemelskaya tundra in the context of climate change
}

\author{
Liudmila Shirokova ${ }^{1,2}$, Irina Ivanova ${ }^{3, *}$ Rinat Manasypov ${ }^{4}$, Oleg Pokrovsky ${ }^{1,2}$, Artem \\ Chupakov $^{1}$, Stanislav Iglovsky ${ }^{1}$, Natalia Shorina ${ }^{1}$, Svetlana Zabelina ${ }^{1}$, Mikhail Gofarov ${ }^{1}$, \\ Dahedrey Payandi-Rolland ${ }^{2}$, Anna Chupakova ${ }^{1}$, and Olga Moreva ${ }^{1}$ \\ ${ }^{1}$ N. Laverov Federal Center for Integrated Arctic Research, RAS, 23 Severnoi Dviny Emb., 119991 \\ Arkhangelsk, Russia \\ ${ }^{2}$ Géosciences Environnement Toulouse (GET), UMR 5563, CNRS-OMP-Université Toulouse, 14 \\ Avenue Edouard Belin, 31400 Toulouse, France \\ ${ }^{3}$ Tomsk branch of the Trofimuk Institute of Petroleum Geology and Geophysics, SB RAS, 4 Avenue \\ Akademichesky, 634055 Tomsk, Russia \\ ${ }^{4}$ BIO-GEO-CLIM Laboratory, Tomsk State University, 36 Avenue Lenina, 634050 Tomsk, Russia
}

\begin{abstract}
In the conditions of climate warming, the thawing of permafrost can provoke the formation of new thermokarst lakes and subsidence, which facilitates the removal of organic matter from thawed peat into natural waters. Hydrochemical studies of surface waters of the Bolshezemelskaya tundra have demonstrated the exponential dependence of the physicochemical parameters on the size of the water body (peat subsidence, thaw ponds, small lakes, thermokarst lakes). The hydrochemical features of thermokarst lakes of the Bolshezemelskaya tundra are determined by high content of DOC, surface runoff and the thickness of peat deposits. Measurements of concentrations and fluxes of methane showed that all studied water bodies of the Bolshezemelskaya tundra are oversaturated with $\mathrm{CH}_{4}$, and depressions, subsidence, and small water bodies $\left(<100 \mathrm{~m}^{2}\right)$ are characterized by the highest concentrations of DOCs. The contribution of these small reservoirs to the total coverage of the surface of the Bolshezemelskaya tundra area is significant, and their consideration can greatly change the assessment of methane fluxes from the arctic tundra.
\end{abstract}

\section{Introduction}

Thawing of permafrost and liberation of dissolved organic carbon (DOC), $\mathrm{CO}_{2}$, and dissolved metals - micronutrients $(\mathrm{Zn}, \mathrm{Mn}, \mathrm{Co}, \mathrm{Ni}, \mathrm{Fe})$ and toxicants $(\mathrm{As}, \mathrm{Cd}, \mathrm{Pb}, \mathrm{Cr})-$ is one of the main negative consequences of climate warming in the subarctic regions [1]. Quantification of the scale of the processes and understanding of the mechanisms involved are the two main challenges of environmental science today.

\footnotetext{
*Corresponding author: IvanovaIS_1986@mail.ru
} 


\section{Objects and main results}

In this article used materials collected by the authors in annual field trip in 2015. Preliminary research on selected pilot sites of the Bolshezemelskaya tundra (BZT) (fig.1) included biogeochemical, microbiological, georadiolocation, Ground Penetration Radar GPR-based studies, remote satellite imaging and hydrological monitoring.

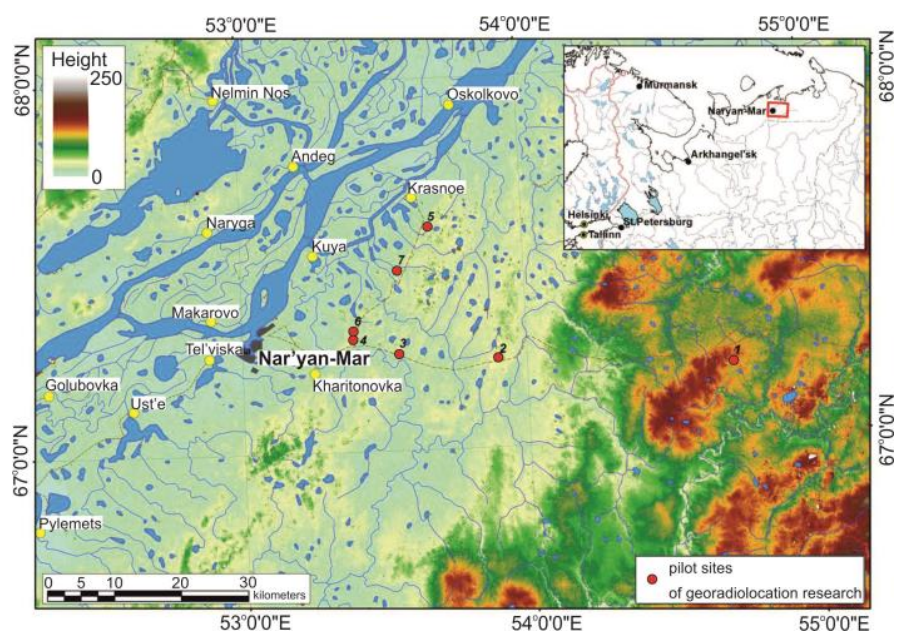

Fig. 1. Scheme pilot sites of the Bolshezemelskaya tundra for georadiolocation research and biogeochemical sampling of thermokarst lakes.

In particular, was performed detailed GPR study of seven key pilot sites in the vicinity of the town of Nar'yan-Mar, where we investigated cryogenic forms of relief development and revealed the main features of soil, mineral substrates, the position of active layer, and the degree of water saturation of underlying deposits (fig. 2).

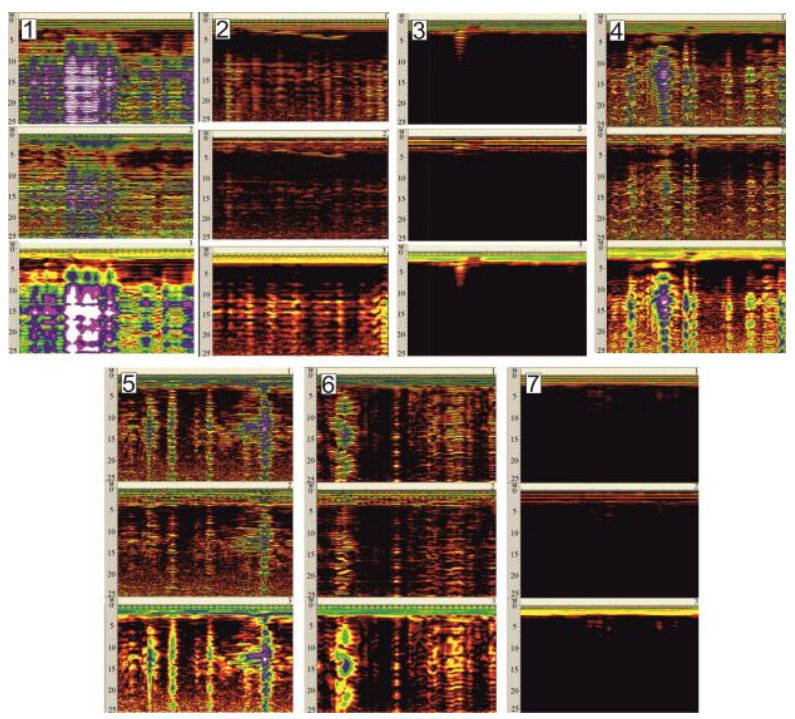

Fig. 2. Fragments of georadarograms on pilot sites of georadiolocation research (1 untreated, 2 - processed using the deconvolution method, 3 - processed using the Hilbert transform) obtained in key areas $(1-7)$ in the vicinity of Naryan-Mar to a depth of $25 \mathrm{~m}$ (antenna subecho-70). 


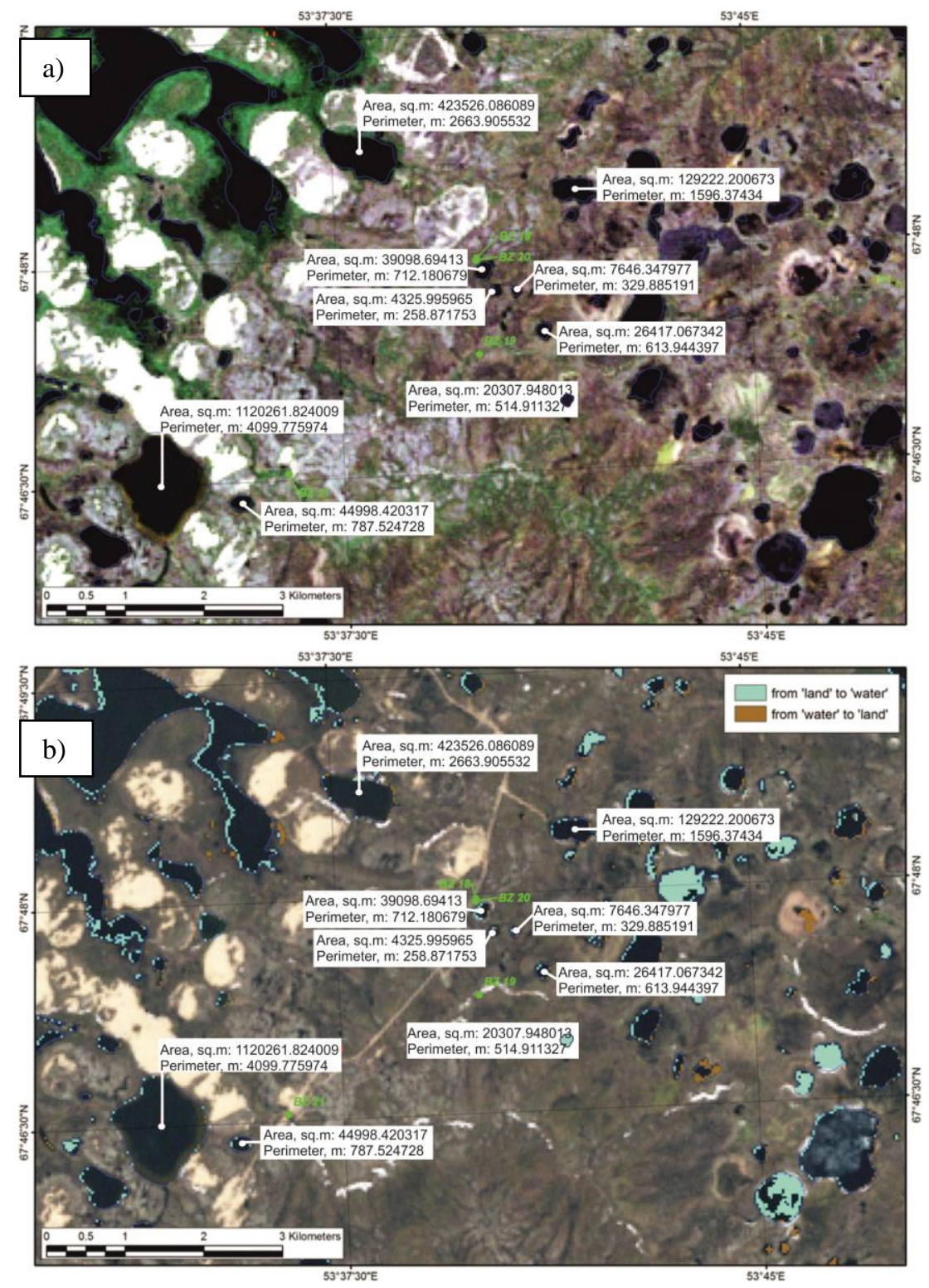

Fig. 3. Processes of permafrost degradation and changes in the area of thermokarst lakes: (a) - Landsat 1985, (b) - Landsat 2001 in the area of reconnaissance.

Biogeochemical and hydrochemical studies of lakes, depressions, thaw ponds, rivers and underground waters revealed complex picture of main hydrochemical parameters depending of the nature of substrate (peat versus mineral deposits), the proximity to the large river (Pechora) and to the arctic coast, and the stage of lake development [2]. In general and in accord with available data for other frozen peat bog regions, there is a systematic decrease of DOC, TDS, Fe (fig. 4) and other metal concentration and an increase of $\mathrm{pH}$ during the maturation of thermokarst water bodies in the sequence "permafrost subsidence - depression - thaw pond - thermokarst lake". As such, first view of the hydrochemistry of thawing permafrost water bodies in BZT is in agreement with that established in Western Siberia low land over past decade [2]. 

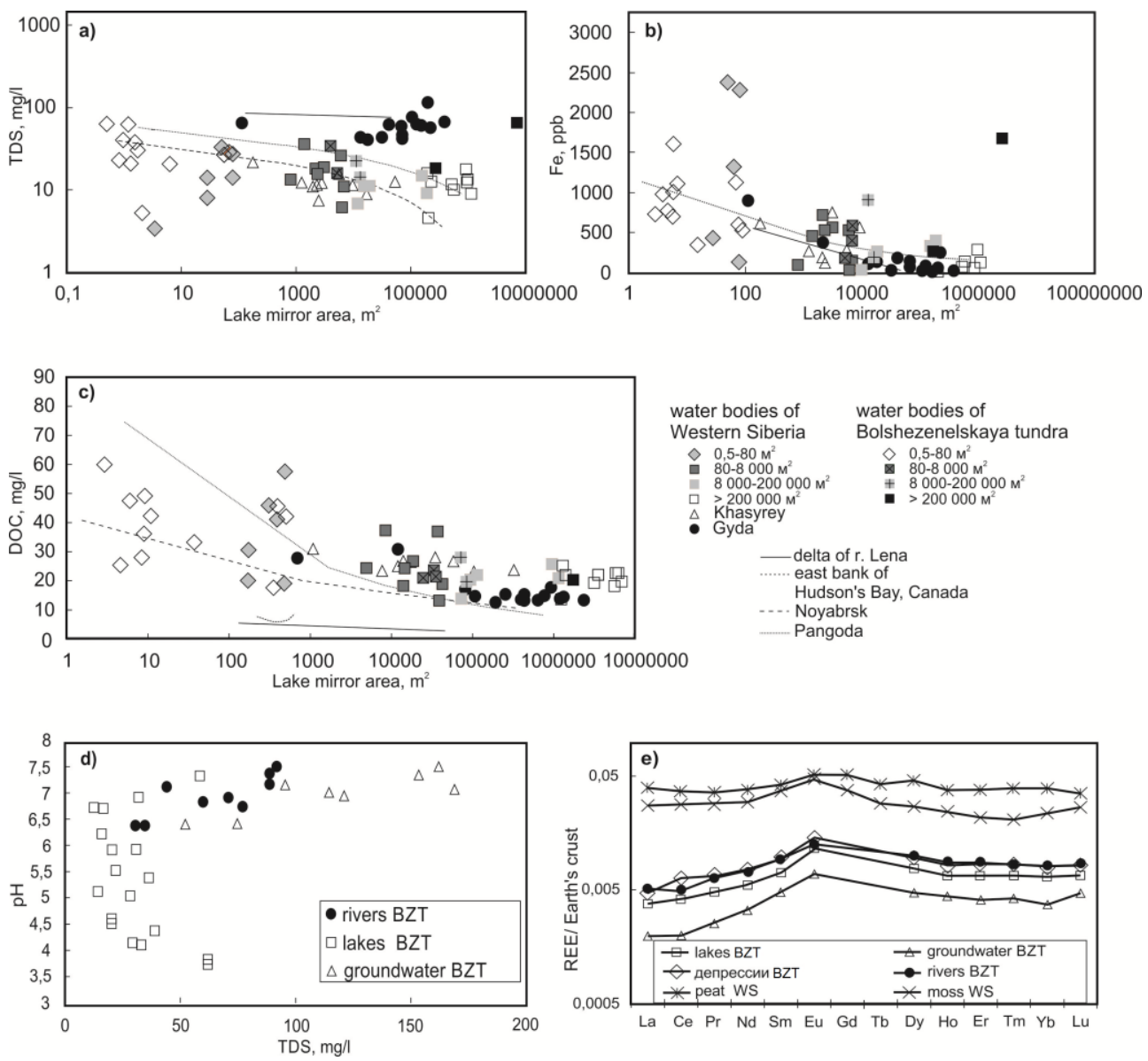

Fig. 4. Hydrochemical characteristics of tested water bodies of the Bolshezemelskaya tundra (BZT) in a comparative aspect with Western Siberia (WS) and Canada.

\section{Conclusion}

In the conditions of climate warming, the thawing of permafrost can provoke the formation of new thermokarst lakes and subsidence, which facilitates the removal of organic matter from thawed peat into surface waters that have a hydraulic connection with groundwater. As a result, underground waters are significantly affected by dissolved organic matter (DOM) of surface waters. Hydrochemical studies of surface waters of the BZT have demonstrated the exponential dependence of the physicochemical parameters on the size of the water body (peat subsidence, thaw ponds, small lakes, thermokarst lakes). The hydrochemical features of thermokarst lakes of the BZT are determined by high content of DOC, surface runoff and the thickness of peat deposits. In general, the elemental composition of thermokarst lake waters of the BZT is different from the lakes in the tundra zone of Western Siberia and is more comparable with the lakes of the northern taiga with elevated concentrations of DOC, $\mathrm{Fe}$ and $\mathrm{Al}$, the content of which is due to peat leaching in the form of organic and organomineral colloids.

Measurements of concentrations and fluxes of methane showed that all studied water bodies of the BZT are oversaturated with $\mathrm{CH}_{4}$, and depressions, subsidence, and small water bodies $\left(<100 \mathrm{~m}^{2}\right)$ are characterized by the highest concentrations of DOCs. These 
small water bodies are not represented on existing maps and databases of world lakes, and contain 3 to 70 times higher methane than large lakes. The contribution of these small reservoirs to the total coverage of the surface of the BZT area is significant, and their consideration can greatly change the assessment of methane fluxes from the arctic tundra.

The research was supported by the Russian foundation for basic research, projects no. 18-55-80015, 19-05-00290.

\section{References}

1. K.L. Balcarczyk, J.B. Jr Jones, R. Jaffe, N. Maie, Biogeochemistry, 94, 255-270 (2009)

2. S.N. Kirpotin, Y. Polishchuk, N. Bryksina, A. Sugaipova, A. Kouraev, E. Zakharova, O.S. Pokrovsky, L.S. Shirokova, M. Kolmakova, R.M. Manassypov, B. Dupre, Int J Environ Stud 68, 5, 603-623 (2011)

3. C.A. Kelly, E. Fee, P.S. Ramlal, J.W.M. Rudd, R.H. Hesslein, C. Anema, E.U. Schindler, Limnol Oceanogr, 46, 1054-1064 (2001) 